Volume 15. Nomor 1. June 2020 Page 93-110
Pandecta
http://journal.unnes.ac.id/nju/index.php/pandecta

\title{
Ambiguitas Hasil Pemantauan dan Evaluasi Dewan Perwakilan Daerah terhadap Rancangan Peraturan Daerah dan Peraturan Daerah
}

\author{
Hanif Hardianto ${ }^{1}$ dan Ratna Herawati ${ }^{2}$
}

1,2Fakultas Hukum, Universitas Diponegoro

DOI: http://dx.doi.org/10.15294/pandecta.v15i1.23842

\begin{abstract}
Article info
\section{Abstrak}

Article History:

Received : March 252020

Accepted: May 302020

Dewan Perwakilan Daerah merupakan lembaga yang dalam pembentukaannya untuk mewakili kepentingan daerah. Tugas dan kewenangan Dewan Perwakilan Daerah diatur dalam Pasal 22 D ayat (1), (2), (3) Undang-Undang Dasar Negara RI Tahun 1945. Tugas dan kewenangan tersebut dijabarkan dalam berbagai peraturan perunPublished: June 152020 - dang-undangan, salah satunya Undang-Undang Nomor 2 Tahun 2018 tentang peru-

Keywords: bahan kedua atas Undang-Undang Nomor 17 Tahun 2014 tentang MPR, DPR, DPD ambiguitas; hasil; pemantuan; dan DPRD. Penelitian ini bertujuan untuk menganalisis hasil pemantauan dan evaluevaluasi; DPD asi DPD terhadap rancangan peraturan daerah dan peraturan daerah, sebagaimana tercantum dalam Pasal 249 ayat (1) huruf j Undang-Undang Nomor 2 Tahun 2018.

ambiguity; the results; monitoring; evaluation; DPD Penelitian dilakukan dengan menggunakan metode yuridis normatif karena bahan hukum perimer yang digunakan adalah peraturan perundang-undangan serta bahan hukum sekundernya adalah literatur dari jurnal dan buku yang berkaitan dengan permasalahan. Hasil penelitian menunjukkan bahwa kewenangan tersebut masih terdapat dualisme karena eksekutif juga memiliki kewenangan untuk memantau dan mengevaluasi rancangan peraturan daerah atau biasa disebut eksekutif preview. Kewenangan yang dimiliki DPD Pasal 249 ayat (1) huruf j Undang-Undang Nomor 2 Tahun 2018 belum memiliki kejelasan mekanisme yang dilaksanakan sehingga menimbulkan ambiguitas dalam pelaksanannya. Untuk memperkuat kejelasan secara yuridis diperlukan perubahan terhadap Undang-Undang Nomor 2 Tahun 2018 dan Undang-Undang Nomor 23 Tahun 2014 tentang Pemerintahan Daerah.
\end{abstract}

\begin{abstract}
Regional Representative Council is an institution in its formation to represent regional intersests. The duties and authorities of the Regional Representative Council are regulated in Article 22 D paragraph (1), (2), (3) of the 1945 Constitution of the Republic Indonesia.these duties and authorities are spelled out in various laws and regulations, one of which is law number 2 of 2018 concerning second amendment to law number 17 if 2014 concerning MPR, DPR, DPD and DPRD. This study aims to analyze the results of DPD monitoring and evaluation of the draft regional regulations and regional regulations, as stated in Articele 249 paragraph (1) letter J of Law Number 2 of 2018. The study was conducted using normative juridicial method because the primer legal material used was legislation and the secondary legal material was literature from journals and books relating on the problem. The results of the study showed that the authority still contained dualism because the executive also had the authority to monitor and evaluate the draft regional regulation or commonly called an executive preview. The authority possessed by DPD Article 249 paragraph (1) letter J of Law Number 2 of 2018 does not yet have a clear mechanism implemented so as to cause ambiguity in its implementation. To strengthen juridicial clarity, it is necessary to amend Law Number 2 of 2018 and Law Number 23 of 2014 concerning Regional Government.
\end{abstract}




\section{Pendahuluan}

Amandemen Undang-Undang Dasar Tahun 1945 membawa dampak besar bagi sistem kelembagaan negara dimana terbentuknya lembaga-lembaga baru yang bertujuan untuk memperkokoh sistem kelembagaan di Indonesia. Kemudian terdapat 3 Lembaga baru yang dibentuk setelah adanya amandemen sebagaimana diatur didalam UndangUndang Dasar Tahun 1945 yaitu Dewan Perwakilan Daerah sesuai Pasal 22C dan Pasal 22D, Komisi Yudisial diatur dalam Pasal 24B serta Mahkamah Konstitusi diatur didalam Pasal 24C. Kemunculan Lembaga baru ini tidak hanya dalam konteks negara Indonesia akan tetapi juga dilakukan oleh negara lain pada tiga dasawarsa terakhir di abad 20 salah satu penyebabnya adalah hampir semua negara modern mempunyai tujuan negara yaitu negara kesejahteraan (welfarestate).

Sebagaian besar lembaga yang dibentuk tersebut adalah lembaga-lembaga yang mempunyai fungsi pembantu, bukan fungsi utama. Lembaga tersebut disebut Auxiliary State's institutions atau Auxiliary State's Organ yang apabila di terjemahkan dalam bahasa Indonesia berarti institusi negara penujang atau organ negara penunjang (Basarah, 2014). Memang benar adanya apabila dikatakan bahwa gejolak demokrasi pada beberapa negara yang membawa dampak terhadap sosial ekonomi sehingga negara mencari formulasi untuk membuat lembaga baru yang digunakan untuk memperbaiki kebijakan-kebijakan dahulu.

Dewan Perwakilan Daerah lahir sejalan dengan tuntutan demokrasi guna memenuhi rasa keadilan masyarakat di daerah, memperluas serta meningkatkan semangat dan kapasitas partisipasi daerah dalam kehidupan nasional, serta memperkuat Negara Kesatuan Republik Indonesia, maka dalam rangka pembaharuan tersebut maka lembaga baru ini oleh Majelis Permusyawaratan Rakyat Republik Indonesia ditetapkan melalui amandemen ketiga Undang-Undang Dasar Negara Indonesia Tahun 1945 UUD 1945 (Arifin, 2019). Ketika sudah terbentuknya lembaga baru ini diharapkan mampu membawa suasana baru didalam parlemen yang ada di Indonesia. Sehingga nuansa sistem kamar lembaga perwakilan pada saat itu tidak hanya berpusat pada Dewan Perwakilan Rakyatnya saja namun juga ada Dewan Perwakilan Daerah dengan fungsi dan wewenang yang berbeda.

Sistem perwakilan dan parlemen di Indonesia berubah dari sistem unikameral (satu kamar) menjadi bikameral (dua kamar). Perubahan tersebut tidak terjadi seketika, tetapi melalui pembahasan yang cukup panjang sebagaimana didalam naskah akademik Undang-Undang Dasar Tahun 1945 buku 3 jilid 2 dimana pembahasan mengenai Dewan Perwakilan Daerah melalui pembahasan pada masa perubahan pertama sampai pada masa perubahan ketiga yang mengahasilkan perubahan sebagaimana didalam Bab VIIA Pasal 22C dan Pasal 22D Undang-Undang Dasar Tahun 1945. Pembahasan ini selain memperhatikan tuntutan politik dan pandangan-pandangan yang berkembang juga melibatkan pembahasan bersifat akademis, dengan mempelajari sistem pemerintahan yang berlaku di negara-negara lain khususnya di negara yang menganut paham demokrasi (Arifin, 2019).

Pada perkembangannya saat pembahasan perlu atau tidaknya lembaga baru di parlemen selain Dewan Perwakilan Rakyat muncullah suatu gagasan untuk membentuk lembaga baru yang dapat mewakili kepentingan-kepentingan daerah dan menjaga keseimbangan antara daerah dan pusat. Tujuan dibentuknya DPD ini untuk menampung aspirasi yang ada di daerah untuk diperjuangkan di tingkat pusat. Munculnya lembaga DPD ini mengindasikan bahwa pada saat sebelum adanya reformasi pengambilan keputusan yang bersifat sentralistik membawa dampak yang besar bagi daearh-daerah yang ada di Indonesia yaitu ketimpangan secara struktur sosial, ekonomi antar daerah masih kuat. Sehingga dibentuknya DPD ini diharapkan mampu untuk membawa aspirasi agar diperjuangkan ditingkat pusat.

Dewan Perwakilan Daerah secara filosofis dalam Pancasila sila ke empat yang berbunyi "kerakyatan yang dipimpin oleh hikmat dalam permusyawaratan dan per- 
wakilan" ekspresi konkret sila 4 Pancasila ini sebagai landasan pembentukan DPD karena perwakilan yang dimaksud tidak hanya dimaknai sebagai perwakilan politik yaitu dari sisi lembaga Dewan Perwakilan Rakyat namun perwakilan daerah juga termasuk untuk mewakili kepentingan daerah ditingkat pusat yaitu Dewan Perwakilan Daerah. Indonesia adalah negara hukum, hal ini sesuai dengan pasal 1 ayat (3) UUD Negara RI Tahun 1945 yang berbunyi "Negara Indonesia adalah negara hukum". Negara hukum mempunyai arti bahwa segala sesuatu yang dijalankan oleh pemerintah Indonesia wajib didasarkan kepada hukum.

Pencantuman negara hukum (rechstaat) bukan negara kekuasaan (machstaat) didalam Pasal 1 ayat 3 UUD NRI 1945. Negara hukum rechstaat bertujuan untuk menyelenggarakan ketertiban umum dimana negara hukum menjaga ketertiban hukum supaya terhindar dari ancaman dan berjalan sesuai hukum. Sedangkan negara kekuasaan machstaat dimana negara bertujuan untuk memelihara dan mempertahankan kekuasaan semata-mata. Pada hakekatnya konsep hukum yang dianut sebenarnya oleh negara Indonesia adalah negara hukum Pancasila dimana sumbernya adalah nilai-nilai sosial budaya Indonesia yang kristalisasinya adalah Pancasila sebagai Dasar Negara (Entah, 2016). Sistem kenegaraan Indonesia yang menggunakan teori pemisahan kekuasaan mempunyai arti bahwa dalam sistem ketatanegaraan Indonesia terdiri atas tiga lembaga tinggi negara yaitu lembaga eksekutif, lembaga legislatif dan lembaga yudikatif. Lembaga legislatif mencerminkan salah satu fungsi lembaga yaitu membuat undang-undang (Budihardjo, 2009). Namun sebelumnya menurut Jimly Asshiddiqie, lembaga negara seperti lembaga legislatif, eksekutif dan yudikatif dapat diartikan dalam beberapa pengertian. Pertama, organ negara paling luas mencakup setiap individu yang menjalankan fungsi law-creating dan law-applying, Kedua, organ negara dalam arti luas tetapi lebih dari pengertian pertama, mencakup individu yang menjalankan fungsi law-creating dan law-applying, Ketiga, organ negara dalam arti yang lebih sempit, yaitu badan atau organisa- si yang menjalankan menjalankan fungsi lawcreating dan/atau law-applying dalam kerangka struktur dan sistem kenegaraan, keempat, lembaga negara terbatas hanya pada pengertian lembaga negara yang dibentuk berdasarkan UUD, UU atau peraturan yang lebih rendah (Nirahua, 2011).

Dalam rangka mereformasi struktur lembaga legislatif di Indonesia maka dibentuk sistem dua kamar yang terdiri atas Dewan Perwakilan Rakyat dan Dewan Perwakilan Daerah, salah satu aspek penting yang melatarbelakangi terbentuknya Dewan PerwakiIan Daerah adalah setelah adanya reformasi tahun 1998 serta amandemen Undang-Undang Dasar Negara RI Tahun 1945 dengan munculnya berbagai lembaga baru dalam kerangka Negara Kesatuan Republik Indonesia salah satunya Dewan Perwakilan Daerah (DPD).

Pembentukan Dewan Perwakilan Daerah ini dititikberatkan akan adanya semangat otonomi daerah, yaitu perlunya sebuah lembaga penjembatan antara daerah dan pusat serta memperjuangkan aspirasi daerah ditingkat pusat. Salah satu alasan dibentuknya Dewan Perwakilan Daerah adalah untuk mengintegrasikan sistem legislasi yang berpihak kepada rakyat dan responsive sesuai dengan kehendak rakyat dan tuntutan reformasi. Latar belakang dibentuknya DPD adalah:

1. Memperkuat ikatan daerah dalam wadah Negara Kesatuan Republik Indonesia dan memperteguh persatuan kebangsaan seluruh daerah

2. Mengingkakan akomodasi dan aspirasi dan kepentingan daerah dalam kebijakan nasional yang berkaitan dengan negara dan daerah.

3. Mendorong percepatan demokrasi, pembangunan dan kemajuan daerah.

4. Mengoptimalkan fungsi utusan daerah yang semula merupakan bagian atau fraksi dari lembaga MPR

Secara regulatif, Dewan Perwakilan Daerah diatur dalam UUD Negara RI Tahun 1945 Pasal 22 C yang menyebutkan:

(1) Anggota Dewan Perwaklan Daerah dipilih dari setiap provinsi melalui pemilihan umum 
(2) Anggota Dewan Perwakilan Daerah dari setiap provinsi jumlahnya sama dan jumlah seluruh anggota Dewan Perwakilan Daerah itu tidak lebih dari sepertiga jumlah anggota Dewan Perwakilan Rakyat.

(3) Dewan Perwakilan Daerah bersidang sedikitnya sekali dalam setahun

(4)Susunan dan kedudukan Dewan Perwakilan Daerah diatur dalam undang-undang.

Merujuk kepada pasal diatas bahwa ketentuan kewenangan dari DPD ini diatur dalam pasal selanjutnya yaitu dalam Pasal 22 D UUD Negara RI Tahun 1945 menyebutkan fungsi legislatif yang dimiliki oleh DPD hanya empat bentuk kegiatan sebagai berikut:

a. Prakarsa pembuatan undang-undang (legislative initation)

b. Pembahasan rancangan undangundang (law making process)

c. Pemberian persetujuan pengikatan atau ratifikasi atas perjanjian atau persetujuan internasional dan dokumen atau persetujuan internasional lainnya (Ulya, 2016)

Wewenang DPD yang berkaitan dengan otonomi daerah berdasarkan UUD NRI Tahun 1945 merupakan kewenangan yang penting namun disisi lain, kewenangan otonomi daerah yang diberikan oleh pemerintah pusat kepada daerah otonom terkait dengan pembentukan sebuah peraturan daerah menjadi dilematik. Hal ini dikarenakan sebelum adanya putusan Mahkamah Konstitusi Nomor 137/PUU-XIII/2015 tentang pembatalan perda oleh eksekutif, perda diawasi oleh lembaga eksekutif bahkan ribuan perda dibatalkan oleh eksekutif, namun setelah adanya putusan MK tersebut maka pengujian perda dikembalikan ke Mahkamah Agung sesuai dengan UU No 12 Tahun 2011 tentang Pembentukan Peraturan Perundang-undangan.

Permasalahan selajutnya muncul karena peraturan daerah yang ada di Indonesia ini tidak hanya berjumlah puluhan bahkan ratusan melainkan ribuan peraturan daerah yang tersebar di berbagai daerah kabupaten/ kota serta provinsi yang ada di Indonesia, apakah menjadi efektif pembatalan peratu- ran daerah oleh Mahkamah Agung. Maka setelah adanya putusan MK tentang penghapusan eksekutif review tersebut, diubahlah UU No 17 Tahun 2014 tentang MPR, DPR, DPD dan DPRD dalam UU No 2 tahun 2018 serta ditambahkan Pasal 249 ayat (1) huruf j yang berbunyi DPD mempunyai kewenangan untuk melakukan pemamantauan dan evaluasi atas rancangan peraturan daerah dan peraturan daerah.

Hal inilah yang menjadi dilematik dalam kewenangan DPD apakah ini merupakan suatu perluasan wewenang atau justru melanggar ketentuan peraturan perundangundangan diatasnya karena secara substansi Pasal 249 ayat (1) huruf $j$ ini sedang diuji di Mahkamah Konstitusi. Namun satu bulan setelah permohonan pengujian tersebut masuk dan mulai di sidangkan oleh majelis, pemohon mencabut permohonan pengujian Pasal 249 ayat (1) huruf $j$ tersebut atas perkara yang teregistrasi dengan nomor 17/PUUXVII/2019 ini yang diajukan oleh perorangan warga negara yang mana pemohon tidak menghadiri sidang kedua uji materi namun mengirimkan surat pencabutan permohonan. Bahkan Permasalahan kembali muncul karena setelah adanya putusan Mahkamah Konstitusi tersebut ternyata eksekutif masih mempunyai kewenangan untuk mengawasi rancangan peraturan daerah dan peraturan daerah namun hanya saja tidak dapat membatalkan peraturan daerah. Oleh karena hal tersebut karena pasal ini masih berlaku sehingga menimbulkan dilematika perluasan kewenangan DPD karena eksekutif juga masih mempunyai kewenangan untuk melakukan preview terhadap peraturan daerah.

Wewenang memantau dan mengevaluasi raperda dan perda oleh DPD tersebut menimbulkan permasalahan karena selain ada dualisme dalam pemantauan dan evaluasi rancangan peraturan daerah dan peraturan daerah dengan eksekutif karena rentan akan terjadi dua hasil pemantauan dan evaluasi yang berbeda dari DPD dan eksekutif. Apabila memakai konsep yang terdapat dalam Undang-Undang Dasar Negara Republik Indonesia Tahun 1945 maka tidak menyebutkan bahwa DPD mempunyai wewenang 
untuk melakukan pemantauan dan evaluasi perda dan raperda yang ada hanya DPD melakukan pengawasan atas pelaksanaan undang-undang mengenai otonomi daerah sesuai Pasal 22 D ayat (3) UUD NRI Tahun 1945.

Artikel penelitian ini berbeda dengan artikel penelitian yang sudah ada, dimana pembahasan dalam artikel penelitian ini lebih dispesifikkan dan difokuskan kepada ambiguitas hasil pemantauan dan evaluasi raperda dan perda yang terdapat dalam Pasal 249 ayat (1) huruf $j$ Undang-Undang Nomor 2 Tahun 2018 perubahan kedua atas Undang-Undang Nomor 17 Tahun 2014 tentang MPR, DPR, DPD dan DPRD daripada penelitian Zada yang membahas tentang “ Kewenangan Legislasi Dewan Perwakilan Daerah dalam Reformasi Kelembagaan Perwakilan Pasca Putusan Mahkamah Konstitusi", penelitian Zaki Ulya yang membahas tentang "Kontradiksi Kewenangan Dewan Perwakilan Daerah Ditinjau Dari Segi Kemandirian Lembaga Dalam Sistem Bikameral" Dan penelitian Widodo yang membahas tentang "Peran dan Fungsi DPD RI dalam Rangka menuju Sistem Bikameral yang Efektif melalui Amandemen". Artikel penelitian ini terdapat dua sub pembahasan yaitu Pertama, tugas dan wewenang Dewan Perwakilan Daerah dalam rangka sistem bikameral yang efektif. Kedua, ambiguitas hasil pemantauan dan evaluasi rancangan peraturan daerah dan peraturan daerah oleh Dewan Perwakilan Daerah.

\section{Metode Penelitian}

Pendekatan penelitian yang digunakan dalam penulisan ini adalah yuridis normatif dengan pendekatan undang-undang sebagai bahan hukum primer untuk mengidentifikasi masalah dan sebagai sarana untuk memberikan solusi dalam norma hukum baru (Sonata, 2014). Jenis data yang digunakan dalam penelitian hukum yuridis normatif ini adalah berupa data primer, sekunder dan tersier. Bahan hukum primer yang digunakan terdiri dari UUD Tahun 1945 dan beberapa peraturan perundang-undangan yang terkait seperti Undang-Undang No 2 Tahun 2018 perubahan kedua atas Undang-Undang No
17 Tahun 2014 tentang MPR, DPR, DPD dan DPRD. Bahan hukum sekunder yang digunakan adalah terdapat kaitannya dengan bahan hukum primer untuk membantu menganalisis bahan hukum primer seperti buku-buku hukum dan jurnal-jurnal hukum. Sedangkan bahan hukum tersier yang digunakan untuk membantu menjelaskan bahan hukum primer dan bahan hukum sekunder seperti Kamus Besar Bahasa Indonesia dan kamus hukum. Dari data-data yang terkumpul kemudian dianalisis melalui pendekatan peraturan perundang-undangan.

\section{Hasil dan Pembahasan}

\section{Tugas dan Wewenang DPD dalam Rangka Sistem Bikameral Yang Efektif}

Prof Jimly Ashidiqie mengemukakan pada saat pertama kali didirikan tahun 1945, struktur parlemen negara kita diidealkan berkamar tunggal (unikameral) tetapi dengan variasi yang dianut dengan teori kedaulatan rakyat yang diimplementasikan dengan perwakilan suara rakyat yang berada di tingkat pusat yaitu Majelis Permusyawaratan Rakyat maka kehendak rakyat secara mendasar seperti pemilihan presiden, menetapkan garis besar haluan negara dan menetapkan UUD bahkan presiden kedudukannya berada dibawah Majelis Permusyawaratan Rakyat (Ashidiqie, 2008). Kemudian menurut Mahfudz MD, salah satu kelemahan dari UUD1945 sebelum adanya amandemen adalah tidak adanya mekanisme check and balances. Presiden menjadi pusat kekuasaan dengan berbagai hak prerogatifnya. Namun setelah adanya reformasi muncullah badan-badan lain yang dibentuk untuk memperbaiki kelemahan-kelemahan didalam pemerintahan Indonesia (Yani, 2018).

Setelah terjadi reformasi pada tahun 1998 muncullah beberapa gagasan didalamnya seperti. Pertama, prinsip pemisahan kekuasaan (separation of power) yang diadopsi oleh negara Indonesia sebagai ganti dari prinsip pembagian kekuasaan (distribution of power) yang berlaku lama sebelum masa reformasi yang ditentukan dalam UUD 1945. Apabila dalam prinsip pembagian kekuasaan yang dulu pembentuk peraturan perundang- 
undangan berada ditangan Presiden dengan persetujuan DPR maka setelah terjadinya pergeseran prinsip menjadi pemisahan kekuasaan ditegaskan bahwa pembentuk peraturan perundang-undangan berada di tangan DPR dan Presiden hanya berhak mengusulkan RUU. Kedua, dalam penyelenggaraan kebijakan nasional terjadi perubahan paradigma sebelum masa reformasi segala sesuatu pembangunan harus ditetapkan persetujuan oleh pemerintah pusat maka setelah adanya reformasi, daerah diberikan hak yang seluasluasnya untuk merancang pembangunan sesuai dengan budaya yang ada didaerahnya masing-masing dan tidak bertentang dengan konstitusi serta kebijakan pusat artinya terdapat perubahan paradigma dari sentralisasi menuju desentralisasi atau otonomi daerah (Ashidiqie, 2008).

Ide awal pembentukan lembaga DPD memang dipikirkan secara matang oleh para ahli hukum pada saat perubahan UUD Tahun 1945 itu bahwasannya dalam praktek ketatanegaraan, baik legislatif bikameral maupu legislatif unikameral masing-masing mempunyai kelebihan dan keuntungan sebagaimana tergambar dibawah ini. kelebihan/keuntungan dalam sistem legislatif bikameral adalah kemampuan anggota untuk:

1. Secara resmi mewakili beragam pemilih (misalnya negara bagian, wilayah, etnik atau golongan);

2. Memfasilitasi pendekatan yang ersifat musyawarah terhadap penyusunan perundang-undangan;

3. Menegah disyahkannya perundangundangan yang cacat atau ceroboh;

4. Melakukan pengawasan atau pengendalian yang lebih baik atas lembaga eksekutif.

Kemudian berikut beberapa keuntungan dalam sistem legislatif unikameral, meliputi:

1. Kemungkinan untuk dengan cepat meloloskan Undang-Undang karena hanya satu badan yan diperlukan untuk mengadopsi Rancangan Undang-Undang sehingga tidak perlu lagi menyesuaikan dengan usulan yang berbeda-beda;
2. Tanggungjawab lebih besar karena anggota legislatif tidak dapat menyalahkan majelis lainnya apabila suatu Undang-Undang tidak lolos atau bila kepentingan warga negara terabaikan;

3. Lebih sedikit anggota terpilih sehingga lebih mudah bagi masyarakat untuk memantau mereka;

4. Biaya lebih rendah bagi pemerintah dan pembayar pajak. (Thaib, 2003) itwipes outthedistrict regulation/district representative and thecomposition ofPeople's Consultative Assembiy, so thatthereis no special position for the Indonesian $\mathrm{Na}^{\wedge}$ onal Armed Forces and The Indonesian Police Force at The People'sConsultative Assembly. The Group Delegate and the representa tive ofThe Indonesian National Armed Forces and The Indonesian Police Force at The People's Consultative Assembly are deleted. Itis taken because theapply ofthis people's representaWe system called bicameral as mentioned above namely Delegate and The Indonesian National Armed Forces/ The Indonesian Police Force can be manifestated through both Group two Legislative Board. Pendahuluan (Studi Konstitusional Perubahan Ketiga UUD 1945).

Oleh karena hal tersebut ketika sudah dirumuskan dan ditentukan oleh para ahli pada saat perubahan UUD Tahun 1945 dan menentukan bahwa yang digunakan di Indonesia adalah sistem legislatif bikameral, semula dimaksudkan dalam rangka mereformasi struktur parlemen di Indonesia menjadi dua kamar (bikameral) yang terdiri dari DPR sebagai perwakilan politik dan DPD sebagai representasi dari daerah dengan struktur bikameral itu diharapkan proses legislasi dapat diselenggarakan berdasarkan sistem "double check" yang memungkinkan representasi kepentingan seluruh rakyat secara relatif dapat disalurkan dengan basis sosial yang lebih luas (Dermawan,). DPD yang merupakan sebuah lembaga baru dalam tatananan hukum kenegaraan di Indonesia menjadi ironi karena perkembangannya melalui sistem parlemen 
dua kamar (bikameral) DPD ini sebenaranya antara ada dan tiada karena para anggotanya dipilih secara demokratis melalui perwakilan setiap daerahnya masing-masing akan tetapi mempunyai kewenangan yang sangat terbatas dalam Pasal 22 C dan D UUD 1945. Fungsi, tugas dan wewenang DPD adalah sebagai berikut.

1. Fungsi Legislasi

DPD mengajukan rancangan undangundang kepada DPR serta ikut membahas berkaitan dengan otonomi daerah, hubungan pusat dan daerah, pembentukan dan pemekaran serta penggabungan daerah, pengelolaan sumber daya alam dan sumber daya ekonomi lainnya. Serta berkaitan dengan perimbangan keuangan pusat.

\section{Fungsi pengawasan}

Pasal 22 D ayat (3) UUD 1945 bahwa DPD dapat melakukan pengawasan atas pelaksanaan undang-undang mengenai: otonomi daerah, pembentukan, pemekaran dan penggabungan otonomi daerah pengelolaan sumber daya alam dan sumber daya ekonomi lainnya, pelaksanaan anggaran pendapatan dan belanja negara, pajak, pendidikan dan agama serta menyampaikan hasil pengawasannya itu kepada DPR sebagai bahan untuk ditindaklanjuti.

\section{Fungsi konsultasi}

Memberikan pertimbangan kepada presiden mengenai RUU APBN, RUU yang berkaitan dengan pajak, pendidikan dan agama serta pemilihan anggota Badan Pemeriksa Keuangan.

\section{Fungsi anggaran}

Dapat mengajukan RUU tentang perimbangan keuangan pusat dan daerah, serta memberikan pertimbangan RUU APBN dan pengawasan terhadap pelaksanaan APBN (Widodo, 2014).

Menurut Mahfudz MD, kewenangan legislasi yang termuat dalam Pasal 22 ayat (1) dan (2) Undang-Undang Dasar 1945, menjadikan Dewan Perwakilan Daerah tidak memiliki peran yang berarti, sebab peran Dewan Perwakilan Daerah sangat terbatas pada hal mengajukan rancangan undang-undang tanpa turut serta dalam menetapkan dan memutus suatu undang-undang, ikut membahas rancangan undang-undang terkait otonomi daerah (Sipangkar, 2018). Oleh karena hal tersebut berkaitan dengan kewenangan legislasi juga diperoleh oleh DPD namun dalam prakteknya kewenangan legislasi mendapat bayang-bayang dari lembaga DPR karena kewenangan legislasi yang diperoleh hanya berupa pengusulan RUU serta ikut membahas namun berbeda halnya apabila kita komparasikan dengan kewenangan yang diperoleh oleh DPR yang sangat besar sekali dalam tataran kenegaraan di Indonesia hal ini membawa dampak diskriminasi kewenangan karena dalam sistem parlemen dua kamar (bikameral) seharusnya mempunyai kewenangan seimbang agar dapat saling check and balances diantara kedua lembaga tersebut.

Mengenai peran Dewan Perwakilan Daerah dalam proses pengawasan yang hasilnya disampaikan kepada Dewan Perwakilan Rakyat sebagai bahan pertimbangan untuk ditindaklanjuti. Dalam bunyi Pasal 22 D ayat 3 UUD Tahun 1945 terdapat frase "dapat" mencerminkan juga bahwa kewenangan pengawasan DPD ini bersifat fakultatif. Kemudian frase "menyampaikan hasil pengawasan kepada DPR" memberikan indikasi bahwa DPD hanya sekedar pengawas serta karena hasil pengawasannya diserahkan kepada DPR sebagai bahan pertimbangan untuk ditindaklanjuti. Jadi pengawasan yang dilakukan DPD terhadap berbagai undangundang yang menjadi kewenangan pengawasannya diserahkan kepada DPR belum tentu diterima dan ditindaklanjuti (Neta, 2014). DPD yang hanya berfungsi melakukan pengawasan yang hasilnya disampaikan kepada DPR sebagai bahan pertimbangan untuk ditindaklanjuti. Oleh karena itu dalam pengawasan DPD tidak lebih hanya sebagai "tukang catat" (Tutik, 2012).

Mengenai fungsi pengawasan yang merupakan bagian dari wewenang DPD yang sudah tercantum dalam Pasal $22 \mathrm{D}$ ayat (3) UUD NRI Tahun 1945 dimaknai sebatas melakukan pengawasan atas pelaksanaan undang-undang otonomi daerah, pembentukan, pemekaran dan penggabungan daerah, hubungan pusat dan daeah, pengelolaan sumber daya alam dan sumber daya ekonomi 
lainnya, pelaksanaan anggaran pendapatan dan belanja negara, pajak, pendidikan dan agama serta menyampaikan hasil pengawasannya itu kepada DPR sebagai bahan pertimbangan untuk ditindaklanjuti. Kemudian munculnya Pasal 249 ayat (1) huruf J dalam Undang-Undang Nomor 2 Tahun 2018 perubahan kedua atas UU Nomor 17 Tahun 2014 tentang MPR, DPR dan DPD yang berkaitan dnegan wewenang DPD untuk memantau dan mengevaluasi raperda dan perda belum ada kejelasan landasan yang digunakan didalam UUD NRI Tahun 1945. Apabila memakai teori stufenbau Hans Kelsen yang digunakan juga didalam UU No 12 Tahun 2011 tentang Pembentukan Peraturan PerundangUndangan Pasal 7 menjelaskan bahwa ada dalam pembentukan hukum menggunakan piramida yang dimulai dari peraturan tertinggi sampai peraturan terendah dan peraturan dibawah tidak boleh bertentangan dengan peraturan yang ada diatasnya.

Apabila diperhatikan lagi fungsi, tugas dan wewenang yang dimiliki DPD hanya menjadi lembaga pembantu saja atau menjadi lembaga pertimbangan DPR dan apabila dibandingkan dengan peran lembaga negara di negara lain yang memiliki kedudukan dan fungsi seperti DPD di Indonesia dengan dua negara pembanding yaitu Amerika Serikat dan Belanda (Tinambunan and Prasetio, 2019). Alasan menggunakan pembanding kedua negara tersebut ada dua yaitu: pertama, berdasarkan dari bentuk dan sistem pemerintahan di Indonesia bahwa negara Amerika Serikat memiliki kesamaan dengan Indonesia yaitu sama-sama memiliki bentuk pemerintahan republik dan sama-sama memiliki sistem pemerintahan presidensial, yang membedakan hanyalah bentuk negaranya saja yaitu kalau Indonesia adalah Negara Kesatuan sedangkan Amerika Serikat adalah Negara Federal. Amerika Serikat sejak tahun 1789 telah membentuk pemerintahan presidensial pertama di dunia. Karena itu dapat disebut sebagao The Mother of Presidential System. Sehingga tidak aneh jika Douglas V. Verney yang dikutip oleh Saldi Isra menyarankan agar sebaiknya terlebih dahulu menelaah sistem politik Amerika Serikat, jika hendak memulai kajian tentag sistem presi- densial (Wiyanto, 2015). Kedua, terkait dengan Belanda hal ini dilandasai bahwa Belnada memiliki hubungan historis dengan Indonesia dikarenakan Indonesia merupakan bagian dari koloni Pemerintahan Hindia Belanda. dampak dari adanya penjajahan Belanda atas Indonesia dalam kepustkaan hukum menghasilkan asas konkordinasi ini adalah membuat beberapa peraturan-peraturan yang diterapkan oleh di Belanda juga diterapkan di negara jajahannya seperti Hindia Belanda diantaranya: KUHP, KUHPer, dan KUHD. Terlebih lagi dampak dari adanya asas konkordinasi ini adalah sistem hukum Indonesia mengutamakan sistem hukum tertulis karena pengaruh yang besar akibat jajahan dari Belanda yang mengenalkan serta mengaplikasikannya di Indonesia (Hoesein, 2012).

Amerika Serikat menganut fungsi legislasi dipegang oleh dua kamar yaitu senate dan house of representative dengan struktur parlemen yang bersifat bikameral dimana kedua kekuaaan memiliki kekuasaan yang berimbang satu dengan yang lainnya atau disebut strong bicameral. Sehingga setiap undang-undang harus memenuhi kedua kamar tersebut. kemudian senate diberi wewenang juga untuk diperbolehkan menyetujui maupun mengusulkan perubahan suatu RUU. Selain itu, senate bersama dengan House Of Representative juga mempunyai kekuasaan yang cukup besar dalam mengajukan suatu RUU kepada Presiden (Tinambunan and Prasetio, 2019). Disini menunjukkan bahwa kedudukan senate atau yang dikenal di Indonesia adalah DPD memiliki tugas dan wewenang sebagai sistem bikameral dalam lembaga legislatif di Amerika Serikat yang sama kuatnya hal ini berbanding terbalik dengan fakta bahwa DPD hanya dijadikan sebagai lembaga bantu atau lembaga penunjang saja kepada DPR yang hanya dapat mengusulkan RUU kepada DPR, ikut membahas dan mengawasi kepentingan daerah.

Belanda melambangkan parlemen yang disebut "the states general" terdiri atas dua kamar yaitu Eerste Kamer (Majelis Tinggi) dan The Tweede Kamer (Majelis Rendah) dimana peran majelis tinggi sebagai regional representatif yang memiliki kesamaan 
dengan DPD yang ada di Indonesia yang masing-masing dipilih berdasarkan daerah/ provinsi dan para anggotanya mewakili daerah masing-masing. Di Belanda kapasitas kedua parlemen relatif sebanding yang terdiri dari kamar pertama (Eerste Kamer) dan kamar kedua (Tweede Kamer). Anggota kedua kamar dipilih dengan caa perwakilan proporsional terbatas untuk jangka waktu 4 tahun. Peran Eerste Kamer lebih banyak saat jointsession dan dalam proses legislasi kamar ini yang akan memutuskan RUU yang dikirim oleh Tweede Kamer (Jurdi, 2016). Apabila dibandingkan dengan keorganisasian yang dimiliki oleh DPD pada hakikatnya memiliki kesamaan dalam hal keterwakilan masing-masing daerah/provinsi yang memilihnya. Namun apabila dibandingkan dengan wewenang yang dimiliki oleh DPD seperti yang tercantum didalam Pasal 22D UUD Tahun 1945 maka jauh perbedaannya. Dimana wewenang DPD tidak kuat dan hanya sebagai pelengkap saja didalam sistem bikameral yang ada di Indonesia.

Sehingga apabila melihat dari kajian perbandingan DPD yang ada di Indonesia dengan DPD yang ada di negara Amerika Serikat dan Belanda maka diperlukan penguatan tugas dan wewenangnya. Namun penerapan penguatan sama rata dengan DPR didalam lembaga legislatif akan besar resikonya alasan yang mendasarinya adalah Pertama, dari segi sejarahnya dahulu yaitu DPR lembaga yang dibentuk dari awal kemerdekaan RI bersama dengan MPR RI. Kedua, dari segi yuridisnya bahwa penguatan tugas dan wewenang dari DPD sulit untuk dilakukan karena didalam amandemen UUD Tahun 1945 sudah dibatasi tugas dan wewenangnya sedemikian rupa sehingga apabila ingin diperkuat lagi tugas dan wewenang dari DPD agar seminimal mungkin sama dengan DPR maka harus diubah dahulu Pasal mengenai tugas dan wewenang DPD didalam UUD Tahun 1945 dan ini memerlukan kekuatan politik yang sangat kuat untuk menekan pemerintahan. Kedua hal itulah yang patut untuk dicermati dalam penguatan tugas dan wewenang DPD agar sama kedudukannya dengan DPR. Oleh karena hal tersebut yang atut untuk dilakukan sekarang ini adalah DPD bekerja secara efektif sesuai dengan amanat konstitusi dan peraturan perundang-undangan.

Apabila dikaji lebih dalam lagi terdapat beberapa hal yang menjadikan suatu parlemen bikameral berjalan efektif. Pertama, untuk membawa kebutuhan dan kepentingan daerah dalam kancah nasional, hal ini tidak akan terlepas dari fungsi, tugas dan wewenang dari DPD karena DPR saja belum cukup untuk membawa tugas serta fungsi ini karena terlepas dari beban politik pragmatis maka DPD seharusnya diberikan wewenang penuh untuk mengembang tugas. Kedua, untuk mendorong kekuatan politik penyeimbang dalam suatu kamar karena tidak bisa dalam satu kamar yang sama terdapat lembaga yang mempunyai melebihi lembaga lain hal ini yang menjadi persoalan bukan pada tubuh DPR itu sendiri akan tetapi ada pada DPD karena dengan penguatan wewenang namun fokus yang berbeda maka akan terjadi kesinambungan antar lembaga DPR dan DPD dalam menjalankan fungsi, tugas dan wewenangnya.

Kedudukan DPD yang saat ini diparadigmakan sebagai lembaga legislatif memiliki tujuan yang sanat penting. Dalam teori struktur parlemen ada tiga prinsip perwakilan yang dijenal di dunia yaitu:

1. Representasi politik (political representation)

2. Representasi teritorial (territorial representation)

3. Representasi fungsional (fungctional representation)

Disini dapat dikaji bahwa perwakilan politik dianggap tidak efektif dan tidak sempurna apabila tidak dilengkapi dengan sistem "double check" sehingga aspirasi dan kepentingan seluruh rakyat benar-benar dapat disalurkan dengan baik. Karena itu diciptakan pula adnaya mekanisme perwakilan daerah (regional representation) atau representasi territorial (Toding, 2017). Kedudukan DPD sebagai sebagai perwakilan menjadi sangat fundamental karena dari segi kedudukan keorganisasiannya sebagai perwakilan dari dari daerah apalagi sekarang ini sudah dialihkannya kebijakan sentralisasi menjadi desentralisasi dimana kewenangan pemerintah daerah 
yang menjalankan otonomi seluas-luasnya dalam bingkai negara kesatuan. Maka diperlukan peran dari DPD untuk menjadi pembawa aspirasi kepentingan daerah masingmasing agar diakomodasi oleh pemerintah pusat melalui kebijaka legislasi (peratiran perundang-undangan).

Tidak dapat dipungkiri bahwa dalam rangka otonomi daerah, setiap daerah memiliki kepetingannya sendiri-sendiri yang harus diperjuangkan di pemerintahan pusat. Disinilah fungsi dan peran Dewan Perwakilan Daerah (DPD) dalam sistem bikameral dalam praktek ketatanegaraan mendatang. Yang harus mendapat perhatian serius adalah betatapun kepentingan daerah tidak boleh diabaikan namun dalam kehidupan berbangsa dan bernegara yang akan datang haruslah dijunjung tinggi komitmen menempatkan kepentingan nasional sebagai prioritas utama. (Thaib, 2003).

Namun apabila dilihat dari kekuatan politik yang saat ini berkuasa tergeser oleh kekuatan politik lainnya bisa saja terjadi prospek lembaga perwakilan yang sekarang ini dianut Undang-Undang Dasar 1945 tidak akan mampu bertahan lama. Hal ini seharusnya menjadi suatu perhatian apabila kedepannya terjadi perubahan UUD 1945 tidak boleh hanya berdasarkan kondisi dan realitas politik akan tetapi yang lebih penting dan pokok justru menitik beratkan pada pendekatan-pendekatan teoritik baik dikadi dari segi filsafat, historis, yuridis, politis dan sosiologisnya. Karena tidak dapat dinafikkan bahwa suatu perubahan dapat diakatakn ideal apabila mengidentifikasi nilai-nilai dan hukum yang hidup didalam masyarakat sehingga pertentangan antara norma lama dan norma baru dapat diusahakan seminimal mungkin. Konstitusi harus dapat mengartikulasi keadaan masa lalu, kini dan mendatang. (Soebardjo, 2007)

Memang tidak berlebihan fungsi dan wewenang DPD hanya sebagai lembaga pembantu saja untuk melengkapi DPR didalam lembaga legislatif. Namun mempertegas dari sisi kelembagaannya perlu untuk dilakukan dengan alasan. Pertama, persolan fundamental dalam berbangsa dan benegara, integrasi bangsa. Hampir semua negara yang memiliki wilayah begitu luas, dengan jumlah penduduk besar serta didalamnya terdapat dinamika dari aneka suku bangsa dan agama, lembaga perwakilannya menganut sistem dua kamar. Apakah negara tersebut berbentuk Kesatuan atau federal dengan sistem pemerintahan presidensil atau parlementer itu bukan soal utama. Bikameralisme tidak selalu dipakai oleh negara berbentuk federal tetapi negara kesatuan yang menerapkan desentralisasi seperti Indonesia juga sangat penting menerapkannya. Bikameralisme harus dimaknai sebagai instrumen untuk memperkuat kesatuan negara. Alasan inilah yang harus pertama kali dikemukaka untuk mempertegas kelembagaan DPD. Daerahdaerah harus diberi ruang gerak yang lebih luas untuk terlibat dalam penyelenggaraan pemerintah. Dan ini berarti para wakil dari daerah harus dipertegas secara politik untuk berperan lebih dari sekedar pelengkap politik di pusat. Kedua, mempertegas bangunan sistem perwakilan Indonesia. Keberadaan DPR dan DPD secara formal memperlihatkan bahwa lembaga perwakilan menganut sistem bikameral. Namun keberadaan lembaga MPR yang secara struktural organisasi memayungi kedua lembaga tersebut menjadikan lembaga parlemen terlihat berbentuk trikameral. Namun disisi lain peran legislasi yang begitu luas dari DPR maka secara politis parlemen Indonesia bersifat unikameral. Ketidakjelasan ini mengundang perdebatan para pakar hukum dan para akademisi maka diperlukan kejelasan. Ketiga, tentu saja memperkokoh sistem check and balances, mulai dari tubuh parlemen sendiri dan selnajutnya bagi antar lembaga kekuasaan negara (eksekutif, legislatif dan yudikatif). Terlepas dari lemnahnya fungsi dan wewenang yang dimiliki DPD, tidak seharusnya DPD menjadikan ini semua sebagai alasan untk tidak bekerja dan berdiam diri. Seharusnya DPD memaksimalkan kinerjanya dengan fungsi dan wewenang yang ada sekarang dengan melakukan upaya untuk meningkatkan peran yang dimiliki. 
Ambiguitas Hasil Pemantauan dan Evaluasi Rancangan Peraturan Daerah dan Peraturan Daerah oleh Dewan Perwakilan Daerah

Dalam teori pengawasan pengaturan daerah. Bahwa dalam hubungan ketatanegaraan antara pemerintah pusat dan pemerintah daerah tidak akan pernah lepas sekalipun konsep yang diberlakukan sekarang ini adalah otonomi daerah yang mempunyai arti pemberian otonomi seluas-luasnya kepada daearh untuk mengurus sendiri urusan rumah tangganya masing-masing sehingga diharapkan membawa dampak yang positif terhadap kemajuan daerah sesuai dengan potensi yang dimilikinya. Pengawasan dalam konsep antara pemerintah pusat dan pemerintah daerah digunakan untuk pengikat kesatuan agar bandul pemberian otonomi daerah dijalankan oleh daerah sehingga daerah tidak melampaui batas dalam hal apapun karena pada hakekatnya pemberian otonomi in digunakan dan dijalankan dengan dasar hukum yang jelas yang mengcau kepada dasar hukum yang berada diatasnya sesuai dengan konsep didalam Undang-Undang Nomor 12 Tahun 2011 tentang Pembentukan Peraturan Perundang-Undangan yaitu peraturan dibawanya harus mengacu kepada peraturan yang ada diatasnya dan tidak boleh bertentangan.

Pengawasan yang terlalu ketat dilakukan Pemerintah Pusat tentunya dapat mengganggu dan mengurangi kebebasan dalam konteks otonomi daerah. Pemerintah Daerah akan merasa terbelenggu dan terbatasinya ruang kerja desentralisasi untuk bekerja secara optimal memberdayakan para pemangku kepentingan did aerah dalam mengelola potensi melayani dan memenuhi kebutuhan masyarakat. Sedangkan disisi lain, bila pengawasan tidak dilakukan secara tepat dan proporsional oleh pemerintah pusat, daerah untuk bergerak melebihi batas kewenangannya sehingga berpotensi mengancam tata pemerintahan dalam bingkai sistem Negara Kesatuan. Untuk itu, ruang kerja pengawasan ini harus memiliki batasan-batasan yang jelas, berupa tujuan dan ruang lingkung pengawasan, bentuk dan jenis pengawasan, tata cara menyelenggarakan pengawasan dan pejabat atau badan yang berwenang melakukan pengawasan. Kemudian terdapat dua jenis pengawasan yang dapat dilakukan yaitu pengawasan bersifat intern dan pengawasan bersifat ekstern. Pengawasan bersifat intern ini merupakan bentuk pengawasan yang dilakukan oleh suatu badan yang secara organisatoris/struktural masih termasuk dalam lingkungan Pemerintah sendiri biasanya pengawasan yang dilakukan ini hanya pengawasan bersifat administrasif atau diebut pula built-in control. Yang kedua adalah pengawasan ekstern yaitu kontorol yang dilakukan secara tidak langsung melalui badan-badan peradilan dalam hal terjadinya persengkataan atau perkara dengan pihak pemerintah daerah dalam hal pembuatan dan pengesahan suatu produk hukum daerah. (Sholikin, M. N., Rofiandri, R., \& Nursyamsi, 2011)

Khusus terkait dengan pengawasan terhadap satuan pemerintahan otonomi, Bagir Manan menyataan ada dua model pengawasan terkait yaitu pengawasan preventif dan pengawasan represif. Kedua model pengawasan ini ditujukan berkaitan dengan pengawasn produk hukum yang dihasilkan daerah maupun pengawasan terhadap tindakan tertentu dari organ pemerintahan daerah, yang dilakukan melalui wewenang mengesahkan dalam pengawasan preventif maupun wewenang pembatalan atau penangguhan daam pengawasan represif. Bila dikaitkan dengan model pengawasan di atas dengan implementasi pengawasan peraturan daerah sebaai salah satu produk penyelenggaraan pemerintahan otonomi, maka model pengawasan preventif ini dilakukan dengan memberikan pengesahan atau tidak memberi pengesahan Peraturan Daerah yang disusun oleh pemerintah Daerah. dimana dalam pengawsan preventif ini, suatu Peraturan Daerah yang dihasilkan hanya dapat berlaku apabila telah terlebih dahulu disahkan oleh penguasa yang berwenang mengesahkan.(Sholikin, M. N., Rofiandri, R., \& Nursyamsi, 2011)

Pengawasan preventif ini dilakukan dalam rangka untuk menyempurnakan suatu produk hukum dari peraturan daerah yang dibentuk karena dengan melalui pengawa- 
san preventif maka akan terlihat kekurangan atau kesalahan-kesalahan dalam prosedur pembuatan peraturan daerah didalam pasalpasalnya hal ini digunakan untuk meminimalisir adanya pengawasan represif yaitu pengujian setelah disahkannya peraturan daerah. Pengawasan preventif ini apabila secara konsep didalam aturannya dilakukan oleh pengawas intern yaitu satuan organisasi pemerintahan daerah karena melalui pengawas intern mereka akan lebih mengetahui permasalahan yang terjadi di daerahnya sehingga pengawasan yang dilakukan akan lebih optimal untuk dilakukan. Kemudian berbeda halnya dengan pengawasan yang bersifat represif karena pengawasan yang bersifat ini dilakukan untuk membatalkan suatu produk hukum peraturan daerah apabila bertentangan dengan Undang-Undang maka pengujiannya dapat dilakukan oleh Mahkamah Agung sehingga peraturan daerah tersebut bisa dibatalkan atau teta berlaku sesuai dengan putusan Mahakamah Agung. Sehingga pengawasan represif ini merupakan bentuk pengawasan yang dapat dilakukan oleh siapapun baik satuan masyrakat atau Lembaga Swadaya Masyarakat untuk menguji peraturan daerah tersebut di peradilan.

Didalam perkembangannya saat ini terdapat dua model pengawasan yang dilakukan terhadap peraturan daerah. pengawasan yang pertama dilakukan oleh eksekutif dalam hal ini diwakili oleh kementerian dalam negeri dimana pengawasan hanya dilakukan dalam hal preventifnya saja yakni mengevaluasi produk rancangan peraturan daerahnya saja sehingga tidak dapat membatalkan suatu produk peraturan daerah yang sudah dibatalkan. Kemudian yang kedua adalah pengawasan yang dilakukan oleh Mahkamah Agung seperti dalam pembahasan diatas bahwa pengawasan ini bersifat represif dapat membatalkan suatu produk peraturan daerah. Namun berjalannya waktu ketika terjadi polemik politik hukum lemahnya tugas, wewenang Dewan Perwakilan Daerah kemudian lembaga ini membuat peraturan ditingkat internalnya berupa peraturan tentang tata tertib dimana didalam pasalnya mengatakan bahwa anggota DPD dapat melakukan pemantauan dan evaluasi terhadap rancangan peraturan daerah dan peraturan daerah. Sehingga saat ini bertambahlah satu model lagi pengawasan yang dilakukan oleh lembaga legislatif. Sehingga benar dikatakan terdapat dampak positif dan negatif didalam pengawasan yang ketat dalam rangka pemberian otonomi daerah yang diberikan pusat kepada daerah. Satu sisi pengawasan yang ketat dapat berdampak terhadap produk hukum peraturan daerah yang baik dan sesuai dengan hierarki pembentukan peraturan perundang-undangan namun disisi lain pengawasan yang super ketat yakni dilakukan melalui tiga model yakni dari lembaga eksekutif oleh Kementerian Dalam Negeri kemudian lembaga legislatif oleh Dewan Perwakilan Daerah dan lembaga yudikatif oleh Mahkamah Agung sehingga apabila dilihat dari teori pengawasan peraturan daerah ini akan memperlambat daerah untuk maju karena disatu sisi pembuatan sebuah produk peraturan daearhnya saja melalui dua tahap awal yakni pengawasan preventif belum lagi apabila terdapat pengujian peraturan tersebut ke Mahkamah Agung sehingga cita-cita pemberian otonomi daerah dalam rangka pemberian otonomi yang seluas-luasnya patut untuk dipertanyakan.

Proses pemantauan dan evaluasi ini saling berkaitan karena pemantauan bisa saja dilakukan dengan pengamatan serta memantau produk rancangan peraturan daerah dan peraturan daerah, namun evaluasi adalah bagian setelah adanya pemantauan yaitu lebih mendalam lagi karena berkaitan pengumpulan bukti untuk mengukur dampak yang ditimbulkan sebelum pemberlakuan peraturan daerah maupun setelah pemberlakuan peraturan daerah. Wewenang Dewan Perwakilan Daerah dalam Pasal 249 ayat (1) yang ditambah 1 huruf dalam Undang-Undang Nomor 2 Tahun 2018 atas perubahan kedua Undang-Undang Nomor 17 Tahun 2017 tentang MPR, DPR, DPD dan DPRD. Wewenang dan tugas DPD ditambah dalam huruf j yaitu: melakukan pemantauan dan evaluasi atas rancangan peraturan daerah dan peraturan daerah. Pasal inilah yang menjadi polemik antara perluasan kewenangan DPD ditengah lemahhnya kewenangan DPD ditingkat pusat dibandingkan dengan DPR. Akan tetapi 
setelah adanya reformasi terdapat beberapa pilihan dalam melakukan pemantauan atau evaluasi bahkan pengujian sebuah produk peraturan perundang-undangan yang ada ditingkat pusat maupun yang ada ditingkat daerah.

Ketentuan mengenai pengujian sudah diatur secara jelas dalam Pasal 9 undang-undang Nomor 12 Tahun 2011 tentang Pembentukan Peraturan Perundang-undangan yang berbunyi : (1) dalam hal suatu UndangUndang diduga bertentangan dengan Undang-Undang Dasar Negara Republik Indonesia Tahun 1945, pengujiannya dilakukan oleh Mahkamah Konstitusi. (2) dalam hal suatu Peraturan Perundang-undangan dibawah Undang-Undang diduga bertentangan dengan Undang-Undang, pengujiannya dilakukan oleh Mahkamah Agung. Secara jelas telah diatur terkait judicial review yang terdapat di ranah Mahkamah Konstitusi dan Mahkamah Agung.

Mengenai ketentuan yang terdapat dalam Undang-Undang Nomor 12 Tahun 2011 juga diatur mengenai kewenangan dalam hal legislatif preview dan review serta eksekutif preview, namun untuk eksekutif review yang sekarang sudah dihapus dengan adanya putusan Mahkamah Konstitusi. Karena dalam sistem ketatanegaraan di Indonesia tidak hanya mengenal judicial review saja dalam hal pemantauan atau evaluasi serta pengujian sebuah produk peraturan perundang-undangan akan tetapi juga mengenal mekanisme lain yang termuat secara yuridis. Mengenani legislatif review merupakan upaya ke lembaga legislatif atau lembaga lain yang memiliki kewenangan legislasi untuk mengubah suatu peraturan perundang-undangan. Misalnya pihak yang keberatan terhadap suatu undang-undang dapat meminta legislatif review ke Dewan Perwakilan Rakyat (DPR).

Perlu diingat dalam legislatif review ini merupakan tahapan dalam pergulatan politik praktis maka dalam pembahasannya pun tidak akan lepas dari kebijakan politik praktis untuk menentukan sikap terhadap pengujian perundang-undangan. Namun konsep tersebut berbeda lagi dengan preview, apabila review menguji lagi sebuah produk peratu- ran perundang-undangan setelah disahkan dan berlaku namun preview melihat atau mengulas lagi sebuah rancangan peraturan perundang-undangan sebelum disahkan, hal ini dilakukan dengan tujuan agar ketika sebuah produk peraturan perudang-undangan disahkan tidak menimbulkan kegaduhan serta mampu menjawab tantangan perubahan zaman dan membawa dampak yang positif terhadap subjeknya.

Lebih lanjut dalam hal kewenangan legislatif preview maupun review ini apabila dikaitkan dengan sistem legislasi nasional maka yang lebih mempunyai peran adalah Dewan Pewakilan Rakyat bukan Dewan Perwakilan Daerah namun karena ini berkaitan dengan pembentukan peraturan daerah maka yang mempunyai lebih wewenangnya adalah Dewan Perwakilan Rakyat Daerah dalam kerangka otonomi daerah, hal ini karena dalam sistem legislasi yang mempunyai kewenangan besar untuk merancang, menyusun, membahas serta mengesahkan dan mengundangkan lebih banyak peran DPR dibanding DPD. Hal ini memiliki dampak terkait kewenangan DPD yang semakin lemah apalagi dalam ketentuan Pasal 249 ayat (1) huruf j UndangUndang Nomor 2 Tahun 2018 menyebutkan bahwa tugas dan kewenangan DPD ditambah yaitu melakukan pemantauan dan evaluasi atas rancangan peraturan daerah dan peraturan daerah.

Konsep mencantumkan Dewan Perwakilan Daerah dalam hal pemantauan dan evaluasi rancangan peraturan daerah dan peraturan daerah muncul karena adanya putusan Mahkamah Konstitusi Nomor 137/PUUXIII/2015 tentang pembatalan perda oleh eksekutif. Pengujian pembatalan perda oleh eksekutif ini tidak akan pernah lepas dengan adanya otonomi daerah, sesuai dengan Pasal 1 ayat (6) Undang-Undang Nomor 23 Tahun 2014 tentang Pemerintahan Daerah bahwa otonomi daerah adalah hak, wewenang, dan kewajiban daerah otonom untuk mengatur dan mengurus sendiri Urusan Pemerintahan dan kepentingan masyarakat setempat dalam sistem Negara Keseatuan Republik Indonesia. Mengacu kepada bunyi pasal tersebut bahwa pemerintah daerah diberikan wewe- 
nang untuk melaksanakan otonomi daerah namun harus sesuai dengan sistem Negara Kesatuan Republik Indonesia artinya ujung dari otonomi daerah ini adalah menyampaikan tanggung jawab kepada pemerintah pusat atas pemberlakuan otonomi dimasingmasing daerah.

Setelah keluarnya putusan Mahkamah Konstitusi tentang pembatalan perda oleh eksekutif ini maka pengujian perda dikembalikan kepada Mahkamah Agung, namun karena menumpuknya kasus di Mahkamah Agung sedangkan proses pengujian terus berlanjut maka Dewan Perwakilan Rakyat mengubah Undang-Undang Nomor 17 Tahun 2014 menjadi Undang-Undang Nomor 2 Tahun 2018 dengan menambah Pasal 249 ayat (1) ditambah 1 huruf yakni huruf j. Namun apabila didalami lagi belum ada kejelasan tugas dan kewenangan DPD dalam hal pemantauan dan evaluasi rancangan peraturan daerah dan peraturan daerah itu masuk ke ranah mana legislatif preview atau review. Karena sejauh ini yang dapat melaksanakan legislatif preview dan review adalah DPR yang merancang, menyusun, membahas, mengesahkan produk perundang-undangan berbeda halnya dengan DPD yang tidak memiliki wewenang apapun dalam hal mengesahkan sebuah produk perundang-undangan hal ini dapat dilihat dalam Pasal 22 D ayat (1), (2) dan (3) UUD 1945.

Bagir Manan berpendapat bahwa pengawasan merupakan unsur yang tidak dapat dipisahkan dari kebebasan berotonomi. Antara kebebasan dan kemandirian berotonomi di suatu pihak dan pengawasan di pihak lain merupakan dua sisi dari satu lembar mata uang dalam negara kesatuan dengan sistem otonomi. Kebebasan dan kemandirian berotonomi dapat dipandang sebagai pengawasan atau kendali terhadap kecendrungan sentralisasi yang berlebihan. Sebaliknya pengawasan merupakan kendali terhadap desentralisasi berlebihan. Tidak ada otonomi tanpa sistem pengawasan. (Manan, 2001)

Implikasi dari adanya aturan yang saling tumpang tindih ini menjadikan pemerintah daerah akan dibuat terhambat apabila hasil pengawasan yang dilakukan oleh Dewan
Perwakilan Daerah dan Menteri Dalam Negeri menunjukkan hasil yang bertentangan, karena Pasal 249 ayat (1) huruf j UndangUndang Nomor 2 Tahun 2018 tentang MPR, DPR, DPRD dan DPD ini tidak memberikan kejelasan lebih lanjut mengenai mekanisme yang digunakan DPD dalam hal melakukan pengamatan dan evaluasi raperda dan perda.

Apabila menggunakan konsep yang ada didalam konstitusi yang hanya memberikan wewenang DPD untuk melakukan pengawasan atas undang-undang otonomi daerah memanglah benar, namun didalam UUD NRI Tahun 1945 Pasal 22 D tidak mencantumkan juga mengenai kewenangan tambahan DPD untuk melakukan pegawasan berupa pengamatan dan evaluasi dari raperda dan perda namun tidaklah benar bahwa DPD juga melakukan pengawasan terhadap produk dari otonomi daerah yang bukan lagi dari ranah didalam undang-undang otonomi daerah karena tujuan awal dibentuknya Dewan Perwakilan Daerah adalah menyerap, menghimpun dan menindaklanjuti asiprasi rakyat dan daerah sekaligus menjadi penghubung kepentingan daerah dan pusat. Dibandingkan dengan pengawasan yang dimiliki oleh eksekutif dalam hal preview sebuah produk peraturan daerah, maka lebih efektif eksekutif karena eksekutif yang lebih mengetahui isi dari rancangan peraturan daerah tersebut karena juga dilibatkan dalam hal pembahasan serta pengesahan dan pemberian nomor registrasi dalam peraturan untuk disahkan dalam lembaran daerah. fungsi pengawasan demikian apabila dikaitkan dengan pengawasan terhadap raperda dan perda yang ada di daerah-daerah sedangkan fungsi pengawasan raperda dan perda tersebut sudah ada di lembaga lain justru wewenang ini akan saling bertumpukkan. Apabila memakai konsep pengawasan DPD yang diberikan konstitusi bahwa semua pengawasan yang dilakukan DPD pada muaranya akan ditindaklanjuti oleh DPR sebagai pengeksekusi jadi disini letak pengawas utamanya adalah DPR dengan logika ini, apabila DPD dengan dasar hukum hanya peraturan tata tertib bersifat internalnya saja untuk melakukan pemantauan dan evaluasi terhadap rancangan peraturan daerah dan peraturan daerah maka seharus- 
nya apabila memakai konsep konstitusi maka wajib disampaikan kepada DPR sebagai pengeksekusi akhir bukan ke DPRD yang ada di daerah karena secara konsep pun lembaga DPRD dibentuk karena adanya pemberian otonomi daerah maka yang menjadi pertanyaan adalah lembaga DPD yang menjadi lembaga legislatif ditingkat pusat tidak akan sampai apabila tetap melaksanakan tugas untuk memantau dan mengevaluasi raperda dan perda.

Kemudian dalam Undang-Undang Nomor 23 Tahun 2014 tentang Pemerintahan Daerah telah diatur secara jelas pembagian otonomi daerah dan desentralisasi serta pembagian wewenang pemerintah pusat dan pemerintah daerah, dalam Pasal 1 angka 6 bahwa otonomi daerah adalah hak, wewenang dan kewajiban daerah otonom untuk mengatur dan mengurus sendiri urusan pemerintahan dan kepentingan masyarakat setempat dalam sistem Negara Kesatuan Republik Indonesia. dengan adanya pemberian otonomi daerah pada saat ini tidak menutup kemungkinan daerah mengalami peningkatan perda yang cukup signifikan, maka diperlukan langkah yang lebih progresif oleh pemerintah pusat dan pemerintah daerah sebagai lembaga eksekutif untuk mengevaluasi rancangan peraturan daerah sebelum disahkan agar sesuai dengan cita-cita pembentukan hukum yang berkeadilan untuk masyarakatnya.

Daerah provinsi merupakan wakil pemerintah pusat yang ada di daerah artinya daerah provinsi akan bertanggung jawab kepada pemerintah pusat atau eksekutif hal ini juga berlaku terhadap pembuatan peraturan daerah provinsi dimana eksekutif yang diwakili oleh kementrian dalam negeri dengan wewenangnya dapat melakukan preview atau pembahasan ulang mengenai suatu rancangan perda sebelum disahkan dan diundangkan, konsep pertanggungjawaban ini diatur dalam Pasal 4 ayat (1) Undang-Undang Nomor 23 Tahun 2014 tentang Pemerintahan Daerah. kemudian daerah kabupaten/ kota bertanggung jawab kepada Gubernur sebagai wakil pemerintah pusat di daerah maka segala produk hukum yang dibuat oleh kabupaten/kota sesuai dengan konsep per- tanggung jawaban maka pemerintahan maka gubernur yang akan melakukan preview tersebut hal ini sesuai dengan Pasal 4 ayat (2) Undang-Undang Nomor 23 Tahun 2014 tentang Pemerintahan Daerah.

Penerapan konsep pengawasan pusat atas daerah dalam konteks otonomi daerah, dalam pandangan Sir William O Hart dan J F Garner dalam (Sulaiman, 2014) merupakan pengikat kesatuan agar bandul kebebasan berotonomi tidak bergerak begitu jauh sehingga mengancam kesatuan, pendapat ini dipertegas kembali oleh Ni'matul Huda bahwa apabila pengikat atau bandul tersebut ditarik begitu keras maka napas kebebasan akan terkurangi. Apabila hal itu terjadi maka pengawasan bukanlah satu sisi dari desentralisasi tetapi menjadi pembelenggu dari adanya konsep desentralisasi. Untuk itu pengawasan harus disertai dengan pembatasanpembatasan.

Pengawasan yang ditujukan kepada pemerintah daerah dilakukan agar meminimalisir kekeliruan-kekeliruan dalam pembuatan suatu kebijkan dalam hal ini adalah penyusunan peraturan daerah. ada beberapa macam bentuk pengawasan yakni pengawasan preview dan review dari pemerintah eksekutif diatasnya, akan tetapi dengan adanya putusan Mahkamah Konstitusi yang membatalkan pengawasan eksekutif review, maka hanya ada eksekutif preview saja yang berlaku, pengawasan preview ini misalnya pengeluaran suatu peraturan yang berlaku sah dan diundangkan harus terlebih dahulu memperoleh persetujuan dari pemerintah diatasnya atau pemerintah daerah tingkat II (Kabupaten/kota) harus terlebih dahulu mendapat persetujuan dari pemerintah daerah tingkat I (Provinsi), kemudian pemerintah daerah tingkat I harus mendapat persetujuan dari pemerintah pusat.

Konsep pengawasan yang dilakukan pemerintah eksekutif diatasnya ujungnya adalah pengesahan peraturan yang diajukan atau tidak. Dalam teori pengesahan ini; pertama, teori yang menyatakan bahwa Raja dan Ratu adalah "medegestfer". Kedua, pengesahan merupakan hak placet. Hak placet adalah hak untuk mencegah atau mengu- 
kuhkan suatu keputusan agar mempunyai atau tidak mempunyai kekuatan mengikat oeh suatu badan pemerintahan yang berbeda dari badan yang membuat keputusan tersebut. Ketiga, pengesahan merupakan suatu tindak lanjut dari suatu keputusan (Sulaiman, 2014). Pengesahan yang dilakukan instansi diatasnya akan memberikan pengaruh besar terhadap suatu peraturan daerah yang akan dibuat karena dengan adanya preview atau pengawasan dan evaluasi terlebih dahulu akan berpengaruh terhadap produk hukum daerah agar sesuai dengan peraturan yang ada diatasnya dan sejalan dengan visi misi pemerintah yang ada diatasnya dalam segala bidang.

Setelah berlakunya Pasal 249 ayat (1) huruf j Undang-Undang Nomor 2 Tahun 2018 perubahan kedua atas Undang-Undang Nomor 17 Tahun 2014 tentang MPR, DPR, DPD dan DPRD tidak terdapat penjelasan lebih lanjut mengenai pasal tersebut didalam penjelasan undang-undangnya dan tidak ada aturan pertanggung jawaban pemberian rekomendasi hasil pemantauan dan evaluasi, namun pertanggung jawaban sebagai pelaksana dari wewenang tersebut diatur didalam Peraturan DPD RI No 3 Tahun 2018 tentang Tata Tertib DPD dalam Pasal 239-243. Didalam Pasal 239 (1) menyebutkan bahwa DPD melakukan Pemantauan dan Evaluasi rancangan Perda dan Perda sebagai pelaksana fungsi reprenstasi. Kemudian penyampaian hasil pemantauan dan evaluasi diatur dalam Pasal 242 ayat (3) yang berbunyi Rekomendasi sebagaimana dimaksud pada ayat (2) disampaikan kepada DPR, Pemerintah Pusat, dan/atau pemerintah daerah sesuai kewenangannya. Pasal 242 ayat (2) berbunyi Hasil evaluasi dilaporkan dalam sidang paripurna sebagai bahan rekomendasi. Pasal 239 ayat (1) yang menyebutkan bahwa DPD melakukan pemantauan dan evaluasi berdasarkan fungsi representasi, sedangkan Peraturan Daerah yang ada di Indonesia sangat banyak yang terdiri dari Peraturan Daerah Provinsi, Kabupaten dan Kota sedangkan DPD hanya ada 1 di tingkat pusat kemudian DPD membentuk Badan Urusan Legislasi Daerah sebagai salah satu pelaksana untuk memantau dan evaluasi tersebut. Pasal 239 (2) Peman- tauan rancangan Perda dan Perda dilaksanakan oleh Anggota masing-masing di daerah pemilihan. Namun anggota DPD dari setiap provinsi adalah 4 orang sedangkan satu provinsi saja Perda yang ada mencapai ribuan apabila ditambah dengan Perda Kabupaten dan Kota, hal ini yang menjadi ambigu dalam wewenanng ini yang tidak dikonsepkan dengan matang.

Hasil pemantauan dan evaluasi yang berupa rekomendasi dilaporkan kepada DPR, Pemerintah Pusat dan/atau pemerintah daerah, akan tetapi menjadi permasalahan selanjutnya adalah ketika hasil evaluasi dilaporkan dalam sidang paripurna hal ini mengakibatkan terhambatnya daerah dalam melaksanakan kinerjanya sedangkan pemerintah daerah karena saat ini dituntut untuk mempercepat pembangunan disegala bidang, kemudian dalam UUD 1945 bahwa kedudukan DPD dan DPR sejajar yakni dalam bidang legislatif kemudian tidak ada keterkaitan antara DPR dengan pemerintahan daerah dalam bidang legislasi untuk membentuk peraturan daerah karena daerah diberikan otonomi untuk menyusun dan membuat peraturan.

Kemudian hasil rekomendasi yang disampaikan kepada pemerintah daerah, tentu hal ini tidak sesuai dengan konsep otonomi daerah karena pengawasan DPD apabila mengacu kepada UUD 1945 hanya kepada Undang-Undang Otonomi Daerah, sedangkan yang diawasi DPD pada Pasal 249 ayat (1) huruf J adalah rancangan peraturan daerah dan peraturan daerah. Apabila dilihat dari sisi lembaganya sudah jelas bahwa DPD merupakan lembaga pusat sedangkan pemerintah daerah adalah lembaga daerah yang sudah diberikan otonomi daerah. kemudian apabila dikaitkan dengan konsep pemerintah daerah bahwa pemerintah daerah hanya dapat bertanggungjawab kepada pemerintah pusat, tidak kepada DPD.

Dari penjelasan diatas dapat dilihat bahwa pengawasan yang dilakukan oleh pemerintah pusat yang diwakili oleh Menteri Dalam Negeri dan Gubernur sebagai wakil pemerinah pusat di daerah memiliki aturan yang jelas dan tegas yang 
diatur dalam Undang-Undang Nomor 23 Tahun 2014 tentang Pemerintahan Daerah. Mengenai ketidakjelasan dalam aturan yang ditambahkan dalam Pasal 249 ayat (1) huruf j Undang-Undang Nomor 2 Tahun 2018 yang kemudian diatur dalam Peraturan DPD Nomor 3 Tahun 2018 tentang Tata Tertib DPD menimbulkan ambiguitas dalam pelaporan hasil rekomendasi pemantauan dan evaluasi rancangan peraturan daerah dan peraturan daerah.

\section{Simpulan}

Berkaitan dengan pengawasan yang dimiliki oleh DPD didalam UUD 1945 tidak mencantumkan pengawasan terhadap rancangan peraturan daerah dan peraturan daerah, namun wewenang tersebut ditambahkan didalam Pasal 249 ayat (1) huruf j Undang-Undang Nomor 2 Tahun 2018, terkait dengan pemantauan dan evaluasi terhadap raperda dan perda ini tidak ada kejelasan lebih lanjut yang diatur di Pasal selanjutnya atau didalam penjelasan undangundang mengenai hasil pemantauan dan evaluasi namun pengaturan selanjutnya diatur di dalam Peraturan DPD Nomor 3 Tahun 2018 tentang Tata Tertib DPD yang mengatur hanya untuk lingkup lembaganya saja padahal penyampaian hasil ini akan berkaitan juga dengan wewenang eksekutif untuk melakukan preview atas peraturan daerah.

Implikasi terhadap disahkannya Undang-Undang Nomor 2 Tahun 2018 terkhusus dalam Pasal 249 ayat (1) huruf j yang berkaitan dengan penambahan kewenangan DPD yang dapat melakukan pemanatauan dan evaluasi terhadap rancangan peraturan daerah dan peraturan merupakan perubahan dalam Undang-Undang. Perubahan wewenang tersebut justru menimbulkan ketidakjelasan pembuat peraturan karena tidak mencantumkan mekanisme yang digunakan dalam hal pelaksanaannya hal ini berdampak terhadap kewenangan lembaga eksekutif yang juga diberikan wewenang yang sama untuk melakukan pengawasan dan evaluasi terhadap rancangan peraturan daerah dan peraturan daerah namun memiliki instrumen yuridis yang jelas serta pembagian wewenang pengawasan terhadap perda provinsi dan kabupaten/kota yang jelas pula.

Berdasarkan hal-hal tersbut diatas, penulis memberikan dua saran yang dapat dilaksanakan dalam rangka memperkuat kedudukan pengawasan Dewan Perwakilan Daerah dalam hal pemantauan dan evaluasi terhadap rancangan peraturan daerah dan peraturan daerah sebagai berikut.

Pertama, memperjelas kedudukan Pasal 249 ayat (1) huruf J dengan UndangUndang Dasar Negara Republik Indonesia Tahun 1945 terkait pemantauan dan evaluasi DPD terhadap Rancangan Peraturan Daerah dan Peraturan Daerah didalam Undang-Undang Nomor 2 Tahun 2018 perubahan kedua atas Undang-Undang Nomor 17 Tahun 2014 tentang MPR, DPR, DPD dan DPRD.

Kedua, ditambahkan penjelasan penyampaian hasil rekomendasi pemantauan dan evaluasi rancangan peraturan daerah dan peraturan daerah oleh DPD didalam perubahan Undang-Undang Nomor 2 Tahun 2018 perubahan kedua atas Undang-Undang Nomor 17 Tahun 2014 tentang MPR, DPR, DPD dan DPRD.

\section{Daftar Pusataka}

Ashidiqie, J. (2008) Struktur Ketatanegaraan Indonesia Setelah Perubahan Amandemen Keempat UUD Negara Republik Indonesia Tahun 1945. Jakarta: Rhieneka Cipta.

Basarah, A. (2014). Kajian Teoritis Terhadap Auxiliary State 'S Organ Dalam Struktur Ketatanegaraan Indonesia. Masalah-Masalah Hukum. 43(1).

Budihardjo, M. (2009). Ilmu Politik. cetakan ke. Jakarta: Gramedia.

Dermawan, M. Kedudukan Dewan Perwakilan Daerah Dalam Kelembagaan Legislatif Menurut Undang-undang Dasar 1945. Legal Opinion: Jurnal Ilmu Hukum. 2(4).

Entah, A. R. (2016). Indonesia: Negara Hukum yang Berdasarkan Pancasila. In Seminar Nasional Hukum Universitas Negeri Semarang. 2(01).

Hoesein, Z. A. (2012). Pembentukan Hukum dalam Perspektif Pembaruan Hukum. Jurnal Rechts Vinding: Media Pembinaan Hukum Nasional. 1(3).

Jurdi, F. (2016). Eksistensi Parlemen Indonesia Setelah Amandemen Konstitusi. Jurnal Hukum Staatrechts, 2(1).

Manan, B. (2001) Menyongsong fajar otonomi daerah. Pusat Studi Hukum, Fakultas Hukum, Universitas Islam Indonesia. 
Arifin, M. Z. (2019). Suatu Pandangan Tentang Eksistensi Dan Penguatan Dewan. Jurnal Thengkyang, 1(1).

Neta, Y. (2014). Upaya Peningkatan Peran Dewan Perwakilan Daerah (DPD) di Indonesia. Fiat Justisia, 5(1).

Nirahua, S. E. (2011). Kedudukan dan Kewenangan Dewan Perwakilan Daerah dalam Sistem Ketatanegaraan Indonesia. Jurnal Hukum Ius Quia lustum, 18(4).

Sholikin, M. N., Rofiandri, R., dkk (2011). Laporan Kajian Implementasi Pengawasan Perda oleh Pemerintah dan Mahkamah Agung. Indonesian Center for Law and Policy Studies.

Sipangkar, L. (2018). Penguatan Fungsi Legislasi Dewan Perwakilan Daerah. Jurnal Legislasi Indonesia, 3(13).

Soebardjo (2007). Dewan Perwakilan Daerah Menurut UUD 1945 Dan Penerapan Sistem Bikameral Dalam Lembaga Perwakilan Indonesia. Jurnal Hukum, 14(1).

Sonata, D. L. (2014). Metode Penelitian Hukum Normatif dan Empiris: Karakteristik Khas dari Metode Meneliti Hukum. Fiat Justisia Jurnal Ilmu Hukum, 8(1).

Sulaiman, K. F. (2014) Dialektika pengujian peraturan daerah pasca otonomi daerah. Pustaka Pelajar.

Thaib, D. (2003). Menuju Parlemen Bikameral (Studi Konstitusional Perubahan Ketiga UUD 1945).
Jurnal Hukum lus Quia lustum. 10(23).

Tinambunan, H. S. R. Prasetio, D. E. (2019). Rekonstruksi Konstitusi Dalam Regional Representative Dewan Perwakilan Daerah Terhadap Fungsi Legislatif. Masalah-Masalah Hukum, 48(3).

Toding, A. (2017). DPD dalam Struktur Parlemen Indonesia: Wacana Pemusnahan Versus Penguatan. Jurnal Konstitusi, 14(2).

Tutik, T. T. (2012). Harmonisasi Fungsi DPD dan DPR pada Lembaga Perwakilan Rakyat dalam Sistem Bikameral Guna Pelaksanaan Checks and Balances. Yustisia Jurnal Hukum, 1(3).

Ulya, Z. (2016). Kontradiksi Kewenangan Dewan Perwakilan Daerah Ditinjau dari Segi Kemandirian Lembaga dalam Sistem Bikameral. Jurnal Hukum Samudra Keadilan, 11(2).

Widodo, W. (2014). Peran Dan Fungsi Dpd Ri Dalam Rangka Menuju Sistem Bikameral Yang Efektif Melalui Amandemen. Jurnal Pembaharuan Hukum Unisulla, 2(1).

Wiyanto, A. (2015). Kekuasaan Membentuk UndangUndang Dalam Sistem Pemerintahan Presidensial Setelah Perubahan Undang-Undang Dasar 1945. Negara Hukum, 6(2).

Yani, A. (2018). Sistem Pemerintahan Indonesia: Pendekatan Teori dan Praktek Konstitusi Undang-Undang Dasar 1945. Jurnal Ilmiah Kebijakan Hukum, 12(2). 